\title{
Performance, Physiological Status, and Rumen Fermentation Profiles of Pre- and Post-Weaning Goat Kids Fed Cricket Meal as a Protein Source
}

\author{
D.A. Astuti* A. Anggraeny, L. Khotijah, S. Suharti, \& A. Jayanegara \\ Department of Nutrition and Feed Technology, Faculty of Animal Science, \\ IPB University (Bogor Agricultural University) \\ Jalan Agatis Kampus IPB Darmaga, Bogor 16680, Indonesia \\ *Corresponding author: dewiapriastuti86@gmail.com \\ (Received 12-02-2019; Revised 22-04-2019; Accepted 23-04-2019)
}

\begin{abstract}
This study was conducted in two experiments with the objectives: (1) to evaluate nutrient intake, physiological status, and performance of pre-weaning goat kids fed with milk replacer containing cricket meal, and (2) to evaluate nutrient intake, rumen fermentation characteristics, blood profiles, and production performance of post-weaning etawah crossbred goats fed with cricket meal as a substitution of soybean meal. Twelve pre-weaning goat kids $(3.78 \pm 0.50 \mathrm{~kg} B W)$ were divided into 3 treatments $(4$ replicates per treatment), i.e., kids fed with goat milk (GM), cow milk (CM), and milk replacer containing cricket meal (MR). In the second experiment, 12 post-weaning goats (12-14 $\mathrm{kg} \mathrm{BW)}$ were fed with 3 dietary treatments, i.e., control ration (CM-0), ration containing 15\% cricket meal (CM-15), and ration containing 30\% cricket meal (CM-30). Parameters measured during 2 months observations were nutrient intake, physiological status, fermentation profiles, blood profiles, and performance. Both experiments used a completely randomized design. Results showed that there were no significant differences in physiological status parameters in pre-weaning goat kids fed with GM, CM or MR. The performance of kids fed with GM was significantly higher $(120 \mathrm{~g} / \mathrm{d})$ than those fed with CM and MR treatments $(\mathrm{p}<0.05)$. In the second experiment, results showed that fat intake in CM-30 was higher than the other treatments $(\mathrm{p}<0.05)$, meanwhile dry matter and nutrient intakes were similar. The average daily gain (ADG), feed efficiency, and rumen fermentation profiles were similar in all treatments. It is concluded that cricket meal can be used in milk replacer without any negative effect on health status. CM-30 ration has good palatability without any negative effect on the rumen fermentation profiles.
\end{abstract}

Keywords: cricket meal; goat kids; milk replacer; rumen fermentation; physiological status

\section{INTRODUCTION}

Demand of products from goat such as milk and meat has markedly increased particularly in the last decade, including the derivative products such as cheese, yoghurt, powder milk, and sausage. Despite such opportunity, goat production on farm has been challenged by the high kid mortality rate that may reach more than 20\% (Astuti et al., 2009). This condition is apparently caused by the low nutrient intake during early birth since the milk produced for the kids is sold in the market for human consumption. The kids typically obtain their milk only a week after parturition and after that all the milk is sold out. As a consequence, the kid may experience low immune status especially for duplet and triplet litter sizes. On the other hand, high milk yield with high price and high litter size provide an opportunity for the farmers to increase their incomes. The use of milk replacer, a formula made by high quality ingredients and has similar nutrient content with the original milk, is an alternative solution to overcome the problem of kid mortality as well as to increase performance before weaning (Krishnamoorthy et al., 2011).
Utilization of high protein sources from edible insects have been popular in recent years, and cricket (Gryllus bimaculatus) is considered as a promising insect species for food and feed (Sánchez-Muros et al., 2014; Rumpold et al., 2013; Makkar 2014). Cricket has been reported to contain $54.10 \%$ crude protein, $26.90 \%$ fat, $6.90 \%$ crude fiber, and $78.90 \%$ total digestible nutrient (TDN) (dry matter basis), and it also contains a number of essential amino acids such as methionine, valine, histidine, lysine, and leucine (Jayanegara et al., 2017). Meanwhile, the fatty acid profiles of cricket are $50.32 \%$ palmitic acid, $32.06 \%$ stearic acid, $9.77 \%$ oleic acid, and $2.34 \%$ linoleic acid (Chakravorty et al., 2014). With the high protein and fat contents, apparently cricket is quite prospective to be used as an ingredient in milk replacer. However, cricket also contains $8.70 \%$ chitin that may disturb nutrient absorption in the digestive tract (Astuti et al., 2016). Cricket is commonly fed to fish and birds (including poultry), while feeding to ruminant is quite rare except for a special purpose (Makkar, 2014). Our previous experiment on sheep showed that cricket meal could be used in the ration of growing sheep without 
causing adverse effect on animal performance (Astuti et al., 2016).

This study was conducted in two experiments with the objectives: (1) to evaluate nutrient intake, physiological status, and performance of pre-weaning goat kids fed with milk replacer containing cricket meal, and (2) to evaluate nutrient intake, rumen fermentation characteristics, blood profiles, and production performance of post-weaning etawah crossbred goats fed with cricket meal as a subtitution of soybean meal.

\section{MATERIALS AND METHODS}

\section{Experiment 1}

This experiment obtained an ethical approval from Bogor Agricultural University Animal Welfare Committee with ACCUC No. 76-2017-IPB. Cricket was obtained from a commercial cricket farm at Bekasi District, West Java Province, Indonesia. Cricket meal was prepared by oven-drying the cricket at $50^{\circ} \mathrm{C}$ for $8 \mathrm{~h}$ and then ground it by a hammer mill to make a meal. Twelve pre-weaning etawah crossbred goat kids, one week old $(3.78 \pm 0.50 \mathrm{~kg} \mathrm{BW})$ were used in this experiment and divided into three treatments (four replicates per treatment). The treatments were control, where the kids received goat milk (GM), kids fed with cow milk $(\mathrm{CM})$, and kids fed with milk replacer containing cricket meal (MR). Nutrient composition of GM, CM, and MR is presented in Table 1. The ingredients for milk replacer apart from cricket meal were egg yolk powder, skim powder, full cream, wheat meal, fish oil, premix, and $\mathrm{CaCO}_{3}$. Total dry matter offered in milk replacer was $3.5 \%$ of $\mathrm{BW}$ and then diluted into warm water $\left(37^{\circ} \mathrm{C}\right)$ with a ratio of $1: 4$. In the second month, the kids were given some concentrate to stimulate the rumen activity. The experimental animals were fed or milked four times a day, i.e., at 8.00 in the morning, 12.00 at noon, 16.00 in the afternoon, and 20.00 in the evening.

Parameters measured were nutrient intake, average daily gain (ADG), respiration rate, heart rate, and rectal temperature, and these parameters were evaluated during 8 weeks of experimental period. The heart rate was measured by counting of korotkoff sound per minute using stethoscope on the left side of the chest. Respiration rate was counted by counting inspiration and expiration cycle for one minute, meanwhile the rec-

Table 1. Nutrient composition of goat milk, cow milk, and milk replacer

\begin{tabular}{lcccc}
\hline \multirow{2}{*}{$\begin{array}{c}\text { Nutrient } \\
(\% D M)\end{array}$} & \multicolumn{3}{c}{ Treatments } & $\begin{array}{c}\text { Commercial } \\
\text { MR }^{1}\end{array}$ \\
\cline { 2 - 5 } \multicolumn{1}{c}{ GM } & CM & MR & FAO \\
\hline Protein & 31.54 & 25.72 & 21.97 & $20-24$ \\
Fat & 50.00 & 15.59 & 25.72 & $20-30$ \\
Lactose & 32.31 & 35.07 & $28.31(\mathrm{NFE})$ & 30.01 \\
Calcium & 0.92 & 1.25 & 1.62 & 1.20 \\
Phosphorus & 1.85 & 1.64 & 0.87 & 0.90 \\
\hline
\end{tabular}

Note: $\mathrm{DM}=$ dry matter, $\mathrm{GM}=$ goat milk, $\mathrm{CM}=$ cow milk, $\mathrm{MR}=$ milk replacer, MR1= FAO recommendation (2011). tal temperature was measured by using body thermometer which was inserted into the rectal of the animals for 5 minutes. Feed intake was measured by weighing the feed offered and feed refusal every day. The nutrient intake was calculated from dry matter intake multiplied by nutrient content of the milk replacer and concentrate. Meanwhile, the average daily gain was measured by weighing the animals every week.

\section{Experiment 2}

Twelve post-weaning etawah crossbred goats $(12 \pm 0.4 \mathrm{~kg}$ BW, 2 months old, continued from the first experiment) were used in this experiment with 3 treatments and 4 replicates of each. The experimental animals were allotted in individual pens for 2 months with a week adaptation period. Cricket meal was prepared with the the same method as in the first experiment. The ingredients of experimental ration were corn meal, pollard, soybean meal, cricket meal, $\mathrm{CaCO}_{3}$, salt, premix, and Brachiaria humidicola grass. The nutrient composition of concentrate is presented in Table 2. The treatments were: $\mathrm{CM}-0=$ concentrate without cricket meal but containing 30\% soybean meal as the control, $\mathrm{CM}-15=$ concentrate containing $15 \%$ cricket meal and $15 \%$ soybean meal, and $\mathrm{CM}-30=$ concentrate containing $30 \%$ cricket meal without soybean meal. Total ration was offered around 3\%-4\% BW (dry matter basis) with a 30:70 ratio of grass and concentrate. The experimental rations were formulated to be isoprotein (CP 18\%) and isoenergy (TDN 71\%). The rations were analysed for proximate according to AOAC (2005), meanwhile the total digestible nutrient (TDN) content was calculated according to the equation of Wardeh et al. (1981) i.e.,TDN $(\% \mathrm{DM})=-37.3039+1.3409(\% \mathrm{CP})+1.3630(\% \mathrm{NFE})+$ 2.1302 (\%EE) - 0.3618 (\% CF).

The rumen fluid was collected $2 \mathrm{~h}$ after feeding time by using a stomach tube with vacuum pump through the mouth one day prior to the end of the experiment. Concentration of VFA was analyzed using gas chromatography equipment (GC 8, Shimadzu Corp., Kyoto, Japan) and ammonia $\left(\mathrm{NH}_{3}\right)$ was measured using the Conway micro-diffusion method (Jayanegara et al., 2016). Proteolytic bacteria population was counted by using roller tube method, meanwhile protozoa population was counted by using Fuchs-Rosenthal counting chamber (Ogimoto \& Imai, 1981). The activity of prote-

Table 2. Nutrient composition of the concentrate for post-weaning goat kids

\begin{tabular}{lccc}
\hline \multirow{2}{*}{ Nutrient (\%DM) } & \multicolumn{3}{c}{ Treatments } \\
\cline { 2 - 4 } & CM-0 & CM-15 & CM-30 \\
\hline Crude protein & 25.04 & 24.66 & 24.28 \\
Ether extract & 2.26 & 5.46 & 8.66 \\
Crude fiber & 5.00 & 4.28 & 3.56 \\
TDN & 74.00 & 74.98 & 75.95 \\
Calcium & 1.31 & 1.36 & 1.41 \\
Phosphorus & 0.79 & 0.73 & 0.66 \\
\hline
\end{tabular}

Note: $\mathrm{TDN}=$ total digestible nutrient, $\mathrm{CM}-0=$ concentrate without cricket meal, CM-15= concentrate containing 15\% cricket meal, C-30= concentrate containing $30 \%$ cricket meal. 
ase enzyme was determined by following the procedure of Brock et al. (1982). Physiological status parameters (rectal temperature, heart rate, and respiration rate), nutrient intake, and goat production performance were measured similar with the first experiment.

\section{Data Analysis}

All data were analyzed with ANOVA based on a randomized complete block design with statistical model as: $\mathrm{Y}_{\mathrm{ij}}=\mu+\alpha_{\mathrm{i}}+\beta_{\mathrm{j}}+\varepsilon_{\mathrm{ij}}$

where $Y_{i j}$ is the observed value, $\mu$ is the mean, $\alpha_{i}$ is the treatment effect, $\beta_{\mathrm{i}}$ is the block effect and $\varepsilon_{\mathrm{ij}}$ is the residual error. Duncan's multiple range test was used for comparison among different treatment means when the ANOVA was significant at $\mathrm{p}<0.05$. All statistic calculations in this experiment were done by using IBM SPSS Statistics software version 20 .

\section{RESULTS}

\section{Experiment 1}

The physiological status of goat kids such as hearth rate, respiration, and body temperature were same in all treatments and in the ranges of normal condition (Table 3). Fresh matter intake of GM (875 g/d) and MR $(847 \mathrm{~g} / \mathrm{d})$ were lower than CM $(986 \mathrm{~g} / \mathrm{d})$, meanwhile the dry matter intake of GM $(98 \mathrm{~g} / \mathrm{h} / \mathrm{d})$ was lower than CM $(120 \mathrm{~g} / \mathrm{h} / \mathrm{d})$ and CM was lower than MR $(203 \mathrm{~g} / \mathrm{h} / \mathrm{d})$ treatment $(\mathrm{p}<0.05)$. The highest protein, fat, and calsium intakes were observed in pre-weaning goat kids fed with MR. The phosphorus intake was similar across all treatments (Table 4). The ADG and final body weights of kids fed with GM and MR were similar and higher compared to CM treatment ( $\mathrm{p}<0.05$; Table 5).

\section{Experiment 2}

Heart rate in post-weaning goats increased during noon as compared to morning and afternoon measure-

Table 3. Physiological status of goat kids during 8 weeks of preweaning age

\begin{tabular}{llccc}
\hline \multirow{2}{*}{ Variables } & Times & \multicolumn{3}{c}{ Treatments } \\
\cline { 3 - 5 } Rectal & Morning & $38.87 \pm 0.26$ & $38.90 \pm 0.28$ & $38.84 \pm 0.26$ \\
temp. $\left({ }^{\circ} \mathrm{C}\right)$ & Noon & $39.40 \pm 0.24$ & $39.45 \pm 0.16$ & $39.55 \pm 0.14$ \\
& Afternoon & $39.36 \pm 0.33$ & $39.19 \pm 0.28$ & $39.13 \pm 0.33$ \\
& Average & $39.21 \pm 0.27$ & $39.18 \pm 0.18$ & $39.17 \pm 0.31$ \\
Heart rates & Morning & $82.53 \pm 4.66$ & $84.86 \pm 6.63$ & $95.88 \pm 14.41$ \\
$(x / m i n)$ & Noon & $111.21 \pm 7.37$ & $92.09 \pm 9.27$ & $112.96 \pm 9.42$ \\
& Afternoon & $87.82 \pm 5.98$ & $92.09 \pm 9.20$ & $87.64 \pm 11.39$ \\
& Average & $93.85 \pm 8.57$ & $89.68 \pm 8.64$ & $98.82 \pm 8.88$ \\
& Morning & $32.50 \pm 4.44$ & $42.25 \pm 5.00$ & $40.41 \pm 6.62$ \\
Respiration & Noon & $37.43 \pm 5.59$ & $40.36 \pm 5.81$ & $42.81 \pm 4.45$ \\
$(x / m i n)$ & Afternoon & $34.61 \pm 4.62$ & $41.36 \pm 5.90$ & $40.14 \pm 6.54$ \\
& Average & $34.84 \pm 5.55$ & $41.32 \pm 5.57$ & $41.12 \pm 5.20$ \\
\hline
\end{tabular}

Note: $\mathrm{GM}=$ goat milk, $\mathrm{CM}=$ cow milk, $\mathrm{MR}=$ milk replacer. ments (Table 6). Heart rate of the experimental goats was quite high, around $120-140$ pulse/min, meanwhile the rectal temperature range was $38.95-39.22^{\circ} \mathrm{C}$ with respiration rate was almost in the upper limit of normal condition (46-49 times/min). The physiological parameters of growing goats was similar in all feeding treatments and were in the normal range. Nutrient intake of post-weaning etawah crossbred goats was generally similar in all treatments except for fat intake; the goats fed with CM-30 had the highest crude fat intake than the other treatments (Table 7).

Concentrations of total VFA, partial VFA, and ammonia in all treatments were similar (Table 8). The utilization of cricket meal to substitute soybean meal up to $30 \%$ in the concentrate had no negative effect on rumen fermentation profiles. All parameters were in normal values to support rumen fermentation activity. Data on rumen microbial population showed that there was no significant difference for protozoa population, total bacteria, proteolitic bacteria, and microbial protein synthesis among the dietary treatments. The performaces of post-weaning etawah crossbred goats are presented in Table 9. The average daily weight gains were similar among the treatments. Similarly, feed efficiency also was not significantly different among CM-0, CM-15, and CM-30 treatments.

\section{DISCUSSION}

\section{Experiment 1}

Milk replacer containing cricket meal apparently indicates no negative effect on the physiological parameters of the goat kids, i.e., rectal temperature, heart rate,

Table 4. Nutrient intake of pre-weaning goat kids during 8 weeks of experiment

\begin{tabular}{lccc}
\hline \multirow{2}{*}{$\begin{array}{l}\text { Nutrient } \\
\text { intake }(\mathrm{g} / \mathrm{h} / \mathrm{d})\end{array}$} & $\mathrm{GM}$ & $\mathrm{CM}$ & $\mathrm{MR}$ \\
\cline { 2 - 4 } & Treatments \\
\hline Fresh matter & $875.86 \pm 12.79^{\mathrm{b}}$ & $986.88 \pm 15.24^{\mathrm{a}}$ & $847.07 \pm 14.07^{\mathrm{b}}$ \\
Dry matter & $98.20 \pm 7.79^{\mathrm{c}}$ & $120.05 \pm 5.24^{\mathrm{b}}$ & $203.87 \pm 3.07^{\mathrm{a}}$ \\
Protein & $30.97 \pm 2.46^{\mathrm{b}}$ & $30.88 \pm 1.35^{\mathrm{b}}$ & $43.97 \pm 0.66^{\mathrm{a}}$ \\
Fat & $31.73 \pm 2.52^{\mathrm{b}}$ & $18.72 \pm 0.82^{\mathrm{c}}$ & $51.40 \pm 0.77^{\mathrm{a}}$ \\
Lactose & $31.73 \pm 1.07^{\mathrm{b}}$ & $33.66 \pm 3.07^{\mathrm{b}}$ & $57.47 \pm 2.05^{\mathrm{a}}(\mathrm{NFE})$ \\
Calcium & $0.90 \pm 0.07^{\mathrm{c}}$ & $1.50 \pm 0.07^{\mathrm{b}}$ & $3.30 \pm 0.05^{\mathrm{a}}$ \\
Phosphorus & $1.82 \pm 0.14$ & $1.97 \pm 0.09$ & $1.77 \pm 0.03$ \\
\hline
\end{tabular}

Note: Mean in the same row with different superscripts differ significantly $(\mathrm{P}<0.05)$. $\mathrm{GM}=$ goat milk, $\mathrm{CM}=$ cow milk, $\mathrm{MR}=$ milk replacer.

Table 5. Nutrient intake of pre-weaning goat kids during 8 weeks of experiment

\begin{tabular}{lccc}
\hline \multirow{2}{*}{ Performances } & \multicolumn{3}{c}{ Treatments } \\
\cline { 2 - 4 } & GM & CM & MR \\
\hline Initial BW $(\mathrm{kg})$ & $3.75 \pm 0.34$ & $3.70 \pm 0.32$ & $3.88 \pm 0.33$ \\
Final BW $(\mathrm{kg})$ & $9.65 \pm 0.54^{\mathrm{a}}$ & $8.53 \pm 0.51^{\mathrm{b}}$ & $9.23 \pm 0.53^{\mathrm{a}}$ \\
ADG $(\mathrm{g} / \mathrm{h} / \mathrm{d})$ & $120.41 \pm 10.00^{\mathrm{a}}$ & $98.47 \pm 20.96^{\mathrm{b}}$ & $109.18 \pm 12.37^{\mathrm{a}}$ \\
Feed efficiency & $1.23 \pm 0.14^{\mathrm{a}}$ & $0.82 \pm 0.12^{\mathrm{b}}$ & $0.54 \pm 0.02^{\mathrm{c}}$ \\
\hline
\end{tabular}

Note: Mean in the same row with different superscripts differ significantly $(\mathrm{P}<0.05)$. $\mathrm{GM}=$ goat milk, $\mathrm{CM}=$ cow milk, $\mathrm{MR}=$ milk replacer. 
Table 6. Physiological response of post-weaning etawah crossbred goats fed with cricket meal

\begin{tabular}{|c|c|c|c|c|c|}
\hline \multirow{2}{*}{ Variables } & \multirow{2}{*}{ Time } & \multicolumn{3}{|c|}{ Treatments } & \multirow{2}{*}{ Normal $^{1}$} \\
\hline & & CM-0 & CM-15 & CM-30 & \\
\hline Rectal temperature & Morning & $38.93 \pm 0.06$ & $38.95 \pm 0.12$ & $38.98 \pm 0.07$ & \multirow{4}{*}{$38.50-40.0$} \\
\hline \multirow{3}{*}{$\left({ }^{\circ} \mathrm{C}\right)$} & Noon & $39.20 \pm 0.06$ & $39.22 \pm 0.10$ & $39.24 \pm 0.04$ & \\
\hline & Afternoon & $39.17 \pm 0.03$ & $39.17 \pm 0.03$ & $39.19 \pm 0.03$ & \\
\hline & Average & $39.10 \pm 0.03$ & $39.11 \pm 0.03$ & $39.13 \pm 0.03$ & \\
\hline \multirow{4}{*}{$\begin{array}{l}\text { Heart rates } \\
\left(x \min ^{-1}\right)\end{array}$} & Morning & $119.59 \pm 6.67$ & $121.13 \pm 3.18$ & $124.92 \pm 6.63$ & \multirow{4}{*}{$70-135$} \\
\hline & Noon & $139.88 \pm 4.71$ & $139.88 \pm 2.05$ & $141.28 \pm 4.31$ & \\
\hline & Afternoon & $132.47 \pm 7.03$ & $132.25 \pm 4.81$ & $133.09 \pm 1.46$ & \\
\hline & Average & $130.64 \pm 2.0$ & $131.08 \pm 1.43$ & $133.09 \pm 1.46$ & \\
\hline \multirow{4}{*}{$\begin{array}{l}\text { Respiration } \\
\left(\mathrm{x} \min ^{-1}\right)\end{array}$} & Morning & $46.13 \pm 2.51$ & $47.54 \pm 3.13$ & $45.69 \pm 2.15$ & \multirow{4}{*}{$26-54$} \\
\hline & Noon & $54.38 \pm 1.59$ & $56.34 \pm 0.61$ & $54.13 \pm 1.15$ & \\
\hline & Afternoon & $49.81 \pm 1.49$ & $50.41 \pm 0.99$ & $48.59 \pm 1.28$ & \\
\hline & Average & $50.10 \pm 0.49$ & $51.43 \pm 0.49$ & $49.17 \pm 0.25$ & \\
\hline
\end{tabular}

Note: $\mathrm{CM}-0=$ concentrate without cricket meal, CM-15= concentrate containing $15 \%$ cricket meal, C-30= concentrate containing $30 \%$ cricket meal. Normal ${ }^{1}$ values (Frandson, 1996).

Table 7. Feed intake of post-weaning etawah crossbred goats receiving dietary treatments $(\mathrm{g} / \mathrm{d})$

\begin{tabular}{lccc}
\hline \multirow{2}{*}{ Variables } & \multicolumn{3}{c}{ Treatments } \\
\cline { 2 - 4 } & CM-0 & CM-15 & CM-30 \\
\hline Total intake $\quad$ & & \\
$\quad$ Grass & 210.32 & 198.33 & 211.81 \\
$\quad$ Concentrate & 538.47 & 532.08 & 481.07 \\
Dry matter & 748.78 & 730.40 & 692.88 \\
Crude fat & $20.34^{\mathrm{a}}$ & $41.17^{\mathrm{b}}$ & $57.35^{\mathrm{c}}$ \\
Crude Protein & 132.08 & 136.55 & 129.33 \\
Crude fiber & 80.23 & 78.20 & 88.82 \\
Calcium & 13.86 & 13.22 & 14.28 \\
Phosphorus & 4.36 & 4.13 & 4.15 \\
\hline
\end{tabular}

Note: Mean in the same row with different superscripts differ significantly $(\mathrm{P}<0.05)$. CM- $0=$ concentrate without cricket meal, $\mathrm{CM}-15=$ concentrate containing $15 \%$ cricket meal, C-30= concentrate containing $30 \%$ cricket meal.

Table 8. Rumen fermentation characteristics of post-weaning goat kids fed concentrate containing cricket meal

\begin{tabular}{lccc}
\hline \multirow{2}{*}{ Variables } & \multicolumn{3}{c}{ Treatments } \\
\cline { 2 - 4 } & $\mathrm{CM}-0$ & $\mathrm{CM}-15$ & $\mathrm{CM}-30$ \\
\hline Fermentation profile & & & \\
Total VFA (mmol/L) & $91.79 \pm 62.82$ & $119.42 \pm 36.42$ & $97.13 \pm 30.98$ \\
Acetic acid (\%) & $45.68 \pm 22.43$ & $48.33 \pm 8.97$ & $53.80 \pm 9.83$ \\
Propionic acid (\%) & $36.78 \pm 11.10$ & $41.49 \pm 8.67$ & $35.58 \pm 12.77$ \\
Butyric acid (\%) & $17.54 \pm 11.81$ & $10.17 \pm 1.92$ & $10.62 \pm 4.28$ \\
Ammonia (mmol/L) & $9.54 \pm 1.63$ & $6.73 \pm 0.82$ & $7.76 \pm 3.50$ \\
Microbial population & & & \\
$\begin{array}{l}\text { Protozoa (log cell/ } \\
\text { mL) }\end{array}$ & $6.25 \pm 0.20$ & $5.93 \pm 0.14$ & $5.74 \pm 0.47$ \\
$\begin{array}{l}\text { Total bacteria (cfu/ } \\
\text { mL) }\end{array}$ & $8.33 \pm 1.29$ & $8.71 \pm 0.56$ & $9.49 \pm 0.73$ \\
\hline $\begin{array}{l}\text { Proteolytic bacteria } \\
\text { (cfu/mL) }\end{array}$ & $9.49 \pm 1.30$ & $9.45 \pm 0.81$ & $9.69 \pm 0.21$ \\
\hline MPS (mg/mL) & $192.46 \pm 54.66$ & $168.4 \pm 65.04$ & $164.33 \pm 39.3$ \\
\hline
\end{tabular}

Note: $\mathrm{CM}-0=$ concentrate without cricket meal, $\mathrm{CM}-15=$ concentrate containing $15 \%$ cricket meal, C-30= concentrate containing 30\% cricket meal, MPS = microbial protein synthesis.
Table 9. Performance and feed efficiency of post-weaning goat kids fed concentrate containing cricket meal

\begin{tabular}{lccc}
\hline \multirow{2}{*}{ Variables } & \multicolumn{3}{c}{ Treatments } \\
\cline { 2 - 4 } & $\mathrm{CM}-0$ & $\mathrm{CM}-15$ & $\mathrm{CM}-30$ \\
\hline Initial weight $(\mathrm{kg})$ & $11.01 \pm 1.79$ & $11.19 \pm 2.29$ & $11.62 \pm 1.82$ \\
Final weight $(\mathrm{kg})$ & $21.79 \pm 4.45$ & $21.42 \pm 4.41$ & $23.19 \pm 5.58$ \\
ADG $(\mathrm{g} / \mathrm{h} / \mathrm{d})$ & $135.30 \pm 30.35$ & $123.41 \pm 37.98$ & $136.54 \pm 39.60$ \\
Feed efficiency $(\%)$ & $20.44 \pm 2.89$ & $20.57 \pm 4.17$ & $23.24 \pm 3.50$ \\
\hline
\end{tabular}

Note: $\mathrm{CM}-0=$ concentrate without cricket meal, $\mathrm{CM}-15=$ concentrate containing $15 \%$ cricket meal, C-30= concentrate containing 30\% cricket meal, $\mathrm{ADG}=$ average daily gain.

and respiration rate were in the normal ranges. The normal values of rectal temperature, heart rate, and respiration rate of goat kids are $38.5-40^{\circ} \mathrm{C}, 26-54$ times/min, and 70-135 pulse/min, respectively (Frandson et al., 2009). On the other hand, the main factors affecting the consumption of milk replacer are palatabilty, milk quality, ambient temperature, age, physiological status, and body weight (McDonald et al., 2011) that further determine production performance of livestock (Krishnamoorthy et al., 2011). The consumption of milk replacer was met the nutrient requirements for goat kids with the body weights around $9 \mathrm{~kg}$. The standard weaning weight of goat kids is $9.72 \mathrm{~kg}$ (Sutama, 2009). Pre-weaning growth is an initial indicator for growth and production due to its genetic correlation with the growth rate in the further stage of growth (Elieser, 2012).

The singlet kid usually has higher gain than duplet or triplet litter size. In this study all kids were produced from singlet and duplet litter size. The total milk from the ewes for the duplet kids should be divided for both kids, so that it affected their performances. The goat milk naturally has mothering immunity for the kids, meanwhile the artificial milk replacer does not have enough mothering immunity compound. Therefore, eventhough nutrient intake of milk replacer group was higher than goat milk group, the performance of goat milk group was better. The high final body weight in goat milk treatment was supported by the efficincy of 
nutrient uptakes and its mothering immunity, meanwhile the performance of kids treated with milk replacer containing cricket meal was due to the high nutrients (protein, fat, and calcium) intake only. The kids milked with goat milk have better performance than those milked with milk replacer containing cricket meal and this difference was related with the differences in the availabilities (digestibility and absorption) of nutrients in both treatments. The goat milk has smaller fat globules which is easier to be digested by the kids. The diameters of individual globules of fat in goat milk ranged from 0.73 to $8.58 \mu \mathrm{m}$. The diameter of particle based on the ratio of volume to surface area of goat milk was 2.76 $\mu \mathrm{m}$. This diameter was less than the mean diameter of $3.51 \mu \mathrm{m}$ for bovine milk (Mayer, 2012). Fat consumption in GM is higher than in CM quantitatively and fat is an efficient energy source. Fat consumption in MR is higher than in GM and CM, however the digestibility and absorption are lower. The immunity compounds in goat milk significantly affect the health status and growth rates of the kids. Goat milk has sialic acid which is located in the surface area of glycoproteins, glycolipids, and free oligosaccharides, and this acid compound is involved in cellular interaction and communication processes. Yasmin et al. (2015) reports that sialic acid of goat milk has several main biological functions such as immune system activation, brain development, and protection against pathogens. This condition was not found in cow milk treatment, where the performance was the lowest compared to the others treatments. Smolders et al. (2012) reported that new born goat kids had low blood vitamin E and selenium concentrations. Research showed that feeding kids with milk replacer resulted in the average daily gain in the first 14 days was $118 \mathrm{~g} / \mathrm{d}$, in the 31 days was $181 \mathrm{~g} / \mathrm{d}$, and following in the 102 days was $165 \mathrm{~g} / \mathrm{d}$. On the other hand, Supriyati (2012) stated that the rate of the pre-weaning kids of Crossbred Etawah goat fed formulated milk replacer grew slower than kids receiving dairy milk. In the present study, the average gain of pre-weaning goat kids (60 days) fed with milk replacer containing cricket meal was $109 \mathrm{~g} / \mathrm{d}$, while in goat kids fed with dairy milk was around 98 $\mathrm{g} / \mathrm{d}$.

Feed efficiency (FE) is defined as a ratio of the daily gain/dry matter intake. The FE value in control treatment was 1.23 , means higher than in milk replacer (0.54) and cow milk (0.82) treatments. Reverdin \& Sauvan (2016) reported that there was a close correlation between FE value and the performances of goat kids, but the FE value could not be explained by the digestibility which was linked to the DMI value.

\section{Experiment 2}

The data of physiological status of pre-weaning kids in this experiment was similar with those reported by Frandson (2009). Increased heart rate and repiration rate are mostly related to ambient temperature, muscle activity, and metabolism processes. Heart rate in young animal is normally higher than in older animal and animal with a larger body size has the slower heart rate (Frandson, 2009). Some factors affecting the heart rate are body temperature, age, body weight, and activity. Respiration rate of growing goats in this experiment is still in the normal condition, similar to that reported by Frandson (2009) that normal respiration rates for goats are 26-54 times/min. The increased respiration rate shows that the animal has increase in body activities, including digestibility and metabolism processes, in order to maintain homeostasis (McDowell et al., 2011). The process of digestion in animals fed with high protein ration caused the increase in specific dynamic action that eventually will increase heart pulse and respiration rate to maintain the homeostasis of heat evaporation processes. Especially in high humidity condition, animals will have difficulty to evaporate the body heat load so that the respiration rate will increase to dissipate body heat load.

The same case with pre-weaning kids in the first experiment was observed that the growing goat has normal rectal temperature which around $38.5-40.0^{\circ} \mathrm{C}$, similar to the range reported by Frandson (2009). In the high ambient temperature, animal will reduce feed intake and increase drinking to regulate body temperature, and this situation will affect the growth and production performances of the animal (McDowell et al., 2011).

Data of nutrient intake in the growing goats showed high fat intake. According to Jayanegara et al. (2017), old cricket contains $26.90 \%$ crude fat. The high fat intake on growing goat will affect rumen fermentation proses, but in this study the growing goat still can tolerate ration with $30 \%$ cricket meal treatment. Cricket meal has high contents of palmitic acid, linoleic acid, and oleic acid i.e, 24.28\%, 25\%, and $22.70 \% \mathrm{w} / \mathrm{w}$, respectively. Wu et al. (2016) reported that methane production would be reduced and beneficial fatty acids would be increased by supplementation of oleic acid in the diet, as in vitro study. Fish oil and sun flower oil in a high concentrate diet caused a time-dependent inhibition of the complete biohydrogenation of 16 and 18 carbon unsaturated fatty acids, and resulted in the accumulation of trans 16:1, trans 18:1, and trans 18:2, 20, and 22 carbon metabolites in ruminal digesta of sheep (Toral et al., 2010).

Protein, carbohydrate, and the other nutrient intakes in cricket treatments are similar with control group meaning that the utilization of cricket meal in the concentrate upto $30 \%$ have good palatability for the growing goat. Astuti et al. (2016) reported that cricket meal in creep feed for growing sheep also has a good palatability.

Result of rumen fermentation by using cricket meal showed that the protozoa population was still in the normal range, similar with the results reported by McDonald et al. (2011) which were $10^{5}-10^{6}$ cells/ $\mathrm{ml}$. Substitution of soybean meal with cricket meal up to $100 \%$ ( $30 \%$ in the concentrate) did not disturb the protozoan activity as in vitro technique, then tended to decrease upto $8.20 \%$ (Jayanegara et al., 2017). This condition will give the good environment and oportunity for bacterial development. The bacterial population in this experiment showed in the normal range with around $10^{8}-10^{9} \mathrm{cfu} / \mathrm{mL}$, and similar with the population reported by McDonald et al. (2011). It seems that 
the utilization of cricket meal can increase the bacterial population. Treatment of CM-30 could increase 13.92\% of total bacteria compared to the control one (Table 8). Total bacterial population in the rumen is depend on the quality of ration, freeding frequency, sampling time, and sampling method of rumen liquor. The proteolitic bacteria are similar in all treatments meaning that substitution of soybean meal with cricket meal in the growing goat still did not affect the proteolitic bacterial population. Jayanegara et al. (2016) stated that feeding with high protein concentrate would activate rumen microbes including proteolitic bacteria so that deamination process will increase. Tropical browse plants, especially legumes, has high potential to increase nutrient supply and to positively manipulate the rumen microbial function (Astuti et al., 2012).

Based on NRC (2007) requirement for growing kids with $150 \mathrm{~g} / \mathrm{d}$ daily weight gain needed $4.81 \%$ body weight (BW) of dry matter intake, $86 \mathrm{~g} / \mathrm{d}$ of protein intake, $0.43 \mathrm{~kg} / \mathrm{d}$ of TDN, $4.80 \mathrm{~g} / \mathrm{d}$ of calcium, and $2.20 \mathrm{~g} / \mathrm{d}$ of phosphorus. The result showed that nutrient intake was suitable and adequate for the requirements of growing kids. Astuti et al. (2016) reported that growth of postweaning etawah crossbred lamb on individual pens was 123 g/d. Sodiq (2012) showed that etawah crossbred lamb with 120 day of age had $128.7 \mathrm{~g} / \mathrm{d}$ growth rate. The feed efficiency in this experiment showed a higher rate compared to the previous result (15\%-17\%) in growing sheep fed cricket meal (Astuti et al., 2016). The better efficiency in this experiment was caused by the quality of cricket meal. Meanwhile Dianingtyas et al. (2017) reported that supplementation of legume wafer in growing etawah crossbred goat could increase daily gain, FE, and IOFC by $55.08 \%, 34.91 \%$, and $14.53 \%$, respectively

\section{CONCLUSION}

Cricket meal could be used in goat kids milk replacer with good palatabilty and resulted ADG around $109 \mathrm{~g} / \mathrm{d}$ without any negative effect on the health status of the animals. The utilization of cricket meal up to $30 \%$ in the concentrate of growing goats has good palatability, no adverse effect on the rumen fermentation profiles, and has similar performance with the control ration.

\section{CONFLICT OF INTEREST}

Authors clarify that there is no conflict of interest with any financial, personal, or other relationships with other people or organization related to the material discussed in the manuscript.

\section{ACKNOWLEDGEMENT}

I would like to thank to The Indonesian Ministry of Research, Technology and Higher Education, who has funded this study through "HIKOM" research grant no. 011/SP2H/LT/DRPM/IV/2017.

\section{REFERENCES}

AOAC. 2005. Official Methods of Analysis of AOAC International. 18th Ed., AOAC International, Gaithersburg, MD., USA.

Astuti D.A., D.R. Ekastuti, Y. Sugiarti, \& Marwah. 2008. Profil darah dan nilai hematologi domba lokal yang dipelihara di Hutan Pendidikan Gunung Walat Sukabumi. J. Agripet. 8: 1-8. https://doi.org/10.17969/agripet.v8i2.599

Astuti, D.A., A.S. Baba, \& I.W.T. Wibawan. 2012. Rumen fermentation, blood metabolites, and performance of sheep fed tropical browse plants. Med. Pet. 34: 201-206. https:// doi.org/10.5398/medpet.2011.34.3.201

Astuti, D.A., L. Khotijah, \& A. Rismarianty. 2016. Utilization of cricket meal as protein source in lamb ration to evaluate nutrient status and rumen fermentation profiles. Indian J. Vet. Sci. Biotech. 11: 49- 53

Dianingtyas, B.D., Y. Retnani, \& D. Evvyernie. 2017. Legume wafer supplementation to increase the performance of post-weaning ettawa grade goats. Med. Pet. 40: 42-46. https://doi.org/10.5398/medpet.2017.40.1.42

Brock, F.M., C.W. Forsberg, \& J.G. Buchanan-Smith. 1982. Proteolytic activity of rumen microorganisms and effects of proteinase inhibitors. Applied Environ. Microbiol. 44: 561-569.

Budisatria, I.G.S., H.M.J. Udo, C.H.A.M. Eilers, E. Baliarti, \& A.J. van der Zijpp. 2010. Preferences for sheep or goats in Indonesia. Small Rumin. Res. 88: 16-22. https://doi. org/10.1016/j.smallrumres.2009.11.002

Chakravorty, J., S. Ghosh, C. Jung, \& V.B. Meyer-Rochow. 2014. Nutritional composition of Chondacris rosea and Brachytrupes orientalis: Two common insects used as food by tribes of Arunachal Pradesh. J. Asia Pac. Entomol. 17: 407-415. https://doi.org/10.1016/j.aspen.2014.03.007

S. Elieser, S. Sumadi, I.G.S. Budisatria, \& S. Subandriyo. 2012. Productivity comparison between boer and Kacang goat dam. Journal of the Indonesian Tropical Animal Agriculture 37: 15-21. https://doi.org/10.14710/ jitaa.37.1.15-21

Frandson, R.D., W.L. Wilke, \& A.D. Fails. 2009. Anatomy and Physiology of Farm Animals. 7th ed. Wiley-Blackwell.

Jayanegara, A., S.P. Dewi, N. Laylli, E.B. Laconi, Nahrowi, \& M. Ridla. 2016. Determination of cell wall protein from selected feedstuffs and its relationship with ruminal protein digestibility in vitro. Med. Pet. 39: 134-140. https://doi. org/10.5398/medpet.2016.39.2.134

Jayanegara, A., M. M. Sholikin, A.N. Della, Sabila, S. Suharti, \& D.A. Astuti. 2017. Nutritive value characterization of cricket (Gryllus assimilis) and its utilization for animal feed: an in vitro evaluation. Pak. J. Biol. Sci. 20: 523-529. https://doi.org/10.3923/pjbs.2017.523.529

Krishnamoorthy, U. \& J. Moran. 2011. Rearing young ruminants on milk replacers and starter feeds. In: Makkar HPS, editor. Animal Production and Health Manual No. 13. Rome (Italy): FAO.

Mayer, H.K. \& G. Fiechter. 2012. Physicochemical characteristics of goat's milk in Austria-seasonal variations and differences between six breeds. Dairy Sci. Technol. 92:167-177. https://doi.org/10.1007/s13594-011-0047-0

McDonald, P., R. Edwards, J.F.D. Greenhalgh, C.A. Morgan, L.A. Sinclair, \& R.G. Wilkinson. 2011. Animal Nutrition. Ashford Colour Press Ltd. Gasport

Makkar, H.P.S., G. Tran, V. Heuze, \& P. Nakers. 2014. State of the art on use of insects as animal feed. Anim. Feed Sci. Technol. 197:1-33. https://doi.org/10.1016/j. anifeedsci.2014.07.008

NRC. 2007. Nutrient Requirements of Small Ruminants Sheep, Goats, Cervids, and New World Camelids. The National Academies Press. Washington, D.C. P.281 
Ogimoto, K. \& S. Imai. 1981. Atlas of Rumen Microbiology. Japan Scientific Society, Tokyo.

Reverdin, S.G. \& D. Sauvant. 2015. Study of the between-goat variation in feed efficiency with a high-concentrate diet. FAO-CIHEAM Network on Sheep and Goats, Jun 2015, Montpellier, France.

Rumpold, B.A. \& K.S. Oliver. 2013. Potential and challenges of insects as an innovative source for food and feed production. Innov. Food Sci. Emerg. Technol. 17:1-11. https://doi. org/10.1016/j.ifset.2012.11.005

Sánchez-Muros, M., F.G. Barroso, \& F. Manzano-Agugliaro. 2014. Insect meal as renewable source of food for animal feeding: A Review. J. Clean. Prod. 65: 16-27. https://doi. org/10.1016/j.jclepro.2013.11.068

Smolders, G., N.V. Eekeren \& W. Govearts. 2012. Effect of vitamin $\mathrm{E}$ and selenium and different types of milk on health and growth of organic goat kids. J. Anim. Sci. 29: 290-6.

Sodiq, A. 2012. Non genetic factors affecting pre-weaning weight and growth rate of ettawah grade goats. Med. Pet. 35: 21-27. https://doi.org/10.5398/medpet.2012.35.1.21

Supriyati. 2012. Pre-weaning growth performance of Etawah Crossbred goats fed milk replacer. Jurnal Ilmu Ternak dan Veteriner 17: 142-151.
Sutama, I.K. 2009. Productive and reproductive performance of female Etawah crossbred goats in Indonesia. Wartazoa 19: 1-6.

Toral, P. G., K. J. Shingfield, G. Hervás, V. Toivonen, \& P. Frutos. 2010. Effect of fish oil and sunflower oil on rumen fermentation characteristics and fatty acid composition of digesta in ewes fed a high concentrate diet. J. Dairy Sci. 93:4804-4817. https://doi.org/10.3168/jds.2010-3300

Wardeh, M.F. 1981. Models for estimating energy and protein utilization for feeds. Ph.D Thesis, Utah State University Logan. https://digitalcommons.usu.edu/etd/4556

Yasmim, R.F.S., M.A.S. Vasconcelos, R.G. Costa, C.A.A. Filho, E.P. de Paiva, \& R.C.R.E. Queiroga. 2015. Sialic acid content of goat milk during lactation. Livestock Sci. 177: 175180. https://doi.org/10.1016/j.livsci.2015.04.005

Wu, D., L. Xu, S. Tang, L. Guan, Z. He, Y. Guan, Z. Tan, X. Han, C. Zhou, J. Kang, \& M. Wang. 2016. Influence of oleic acid on rumen fermentation and fatty acid formation in vitro. PLoS One. 11: e0156835. https://doi.org/10.1371/journal. pone. 0156835 